Review Article

\title{
Expression of Stem Cell and Epithelial-Mesenchymal Transition Markers in Circulating Tumor Cells of Breast Cancer Patients
}

\author{
Natalia Krawczyk, Franziska Meier-Stiegen, Malgorzata Banys, Hans Neubauer, \\ Eugen Ruckhaeberle, and Tanja Fehm \\ Department of Obstetrics and Gynecology, University of Duesseldorf, Moorenstraße 5, 40225 Duesseldorf, Germany \\ Correspondence should be addressed to Natalia Krawczyk; natalia_krawczyk@yahoo.de
}

Received 12 January 2014; Revised 25 March 2014; Accepted 26 March 2014; Published 8 May 2014

Academic Editor: Amanda B. Spurdle

Copyright (c) 2014 Natalia Krawczyk et al. This is an open access article distributed under the Creative Commons Attribution License, which permits unrestricted use, distribution, and reproduction in any medium, provided the original work is properly cited.

Evaluation and characterization of circulating tumor cells (CTCs) have become a major focus of translational cancer research. Presence of CTCs predicts worse clinical outcome in early and metastatic breast cancer. Whether all cells from the primary tumor have potential to disseminate and form subsequent metastasis remains unclear. As part of the metastatic cascade, tumor cells lose their cell-to-cell adhesion and undergo epithelial-mesenchymal transition (EMT) in order to enter blood circulation. During EMT epithelial antigens are downregulated; thus, such tumor cells might elude classical epithelial marker-based detection. Several researchers postulated that some CTCs express stem cell-like phenotype; this might lead to chemoresistance and enhanced metastatic potential of such cells. In the present review, we discuss current data on EMT and stem cell markers in CTCs of breast cancer and their clinical significance.

\section{Introduction}

Presence of disseminated tumor cells (DTCs) in bone marrow and circulating tumor cells (CTCs) in peripheral blood of primary breast cancer patients was shown to be associated with impaired clinical outcome $[1,2]$. Moreover, the persistence of CTCs/DTCs after completion of adjuvant treatment also represents a negative prognostic factor [3-5]. These cells are therefore assumed to be a surrogate marker of minimal residual disease and precursors of distant metastasis. Despite the prognostic relevance of tumor cell dissemination, detection of tumor cells in blood or bone marrow is not necessarily followed by relapse of disease. While most of these cells are already apoptotic or dead and others will successfully be eliminated by shear forces of the bloodstream, only a small group of CTCs possesses the ability to extravasate and migrate through the endothelial cell layer [6-10]. Merely a fraction of those is able to survive at secondary sites and cause tumor growth "metastatic inefficiency" [11, 12]. Although factors determining the fate of CTCs still remain to be elucidated, one presently discussed theory considers epithelial-mesenchymal transition (EMT) to be a crucial step in tumor cell dissemination.

EMT is a phenomenon hypothesized to contribute to cancer progression and metastasis [13]. In this process epithelial cells of the primary tumor undergo a series of phenotypic changes, such as reduction of cell-cell adhesion, increment in cell mobility and invasiveness, loss of epithelial markers, and acquisition of mesenchymal phenotype [14]. Moreover, it has been demonstrated that the process of EMT can generate cells with stem cell-like properties [15]. Cancer cells with stem cell-like, self-renewal capabilities (cancer stem cells: CSCs) are currently regarded to be the source of metastatic tumor spread [16]. Since CTCs have been shown to express mesenchymal and stem cell markers, it has been recently postulated that EMT plays a key role in the process of tumor cell dissemination [17-20]. In consequence, tumor cells undergoing EMT may migrate into peripheral blood as CTCs. Due to their mesenchymal stemness features, these cells might be able to reach distant sites of the body and initiate metastases. In the following review we will discuss current data on the EMT and stem cell markers in CTCs of breast cancer and their clinical relevance. 


\section{Tumor Cell Dissemination and Its Role in the Metastatic Cascade}

Distant metastasis represents the major cause of morbidity and mortality in breast cancer patients $[21,22]$. Tumor cell dissemination is a phenomenon that occurs in the very early stage of carcinogenesis and is thought to be a potential source of metastatic disease [23]. Disseminated tumor cells in bone marrow can be detected in up to $30-40 \%$ of primary breast cancer patients at the time of diagnosis and are strongly associated with impaired prognosis [1]. Depending on the sensitivity of the assay used and stage of disease, the detection rates of CTCs in peripheral blood range from 10 up to $80 \%$; prognostic relevance of CTCs has been recently confirmed by several clinical trials both in the adjuvant and in the metastatic setting. However, data on CTC prevalence and their clinical significance, especially in early breast cancer, are to date incoherent [24-37]. Hematogenous spread of tumor cells into blood circulation of patients with solid malignancies has been a known phenomenon for a long time [35, 38, 39]. While numerous tumor cells daily reach peripheral blood, only a small fraction of these cells has the ability to survive and to arrive at secondary homing sites "metastatic inefficiency" $[11,12]$. Moreover, their seeding at the secondary sites is not a random process. As suggested by Paget in the "seed and soil" hypothesis from 1889 and confirmed by several studies, the interactions between circulating tumor cells "seeds" and the microenvironment of their potential homing sites "soil" play a crucial role in the formation of metastasis [38, 40-42]. These findings are in accord with clinical data; a pooled analysis of nine studies involving 4703 primary breast cancer patients demonstrated that more than half of patients with disseminated tumor cells in bone marrow at the time of diagnosis do not develop metastatic disease [1]. CTCs seem to represent a highly heterogeneous cell population with regard to their morphology, molecular characteristics, implantation efficiency after dissemination and their metastatic potential [43-45].

\section{EMT/MET}

Epithelial-mesenchymal transition is a process well known from embryogenesis. In order to reach their final destination, embryonic epithelial cells acquire functional and phenotypic properties of migratory, invasive mesenchymal cells and thus become detached from the surface of the embryo [46, 47]. Interestingly, epithelial-mesenchymal transition represents a reversible mechanism; once the target localization has been reached, these cells undergo a reverse process of mesenchymal epithelial transition (MET) and recover their epithelial character to proliferate and form differentiated tissues [48]. This phenomenon, essential for embryonic development, has been recognized to represent a crucial step in tumor progression and metastasis [13].

The process of EMT involves the loss of cell-to-cell adhesions, loss of apicobasal cell polarity, and increment of migratory and invasive features of mesenchymal cells [48]. EMT can therefore compromise the mechanical integrity of the tissue [49]. EMT, once induced in tumor cells, may allow them to escape from primary tumor, migrate through the blood unaffected by therapeutic agents, and reach the site of future metastasis. Furthermore, it has been postulated that MET also represents the part of metastatic formation and that tumor cells regain their epithelial properties at their secondary homing sites $[50,51]$. This hypothesis is in accord with the observation that metastatic lesions generally share epithelial features of the primary tumor (e.g., E-cadherin expression) $[52,53]$.

EMT process can be induced by extracellular factors like transforming growth factor $\beta(\operatorname{TGF} \beta)$, Wnt, Notch, epidermal growth factor (EGF), hypoxia, and others [48]. Numerous transcription factors inducing EMT, like SNAIL, TWIST, SLUG, ZEB1, ZEB2, and FoxC2, have been evaluated [54]. Loss of E-cadherin, overexpression of N-cadherin, and cytoskeletal alterations (e.g., expression of vimentin) hallmark this process causing phenotypical and structural changes that lead to acquisition of motility and invasiveness of cells that have undergone EMT. Several studies have shown a correlation between EMT process and high aggressiveness of breast cancer. EMT markers seem to be associated with basal-like breast cancer phenotype and, therefore, with high invasiveness and metastatic potential $[55,56]$. Table 1 summarizes markers used for detection and characterization of CTCs showing epithelial as well as mesenchymal phenotypes.

\section{Detection of Tumor Cell Dissemination}

The challenge in identifying and detecting CTCs is based on their rare number as well as the lack of a universal breast cancer marker. The majority of methods currently used are based on the detection of epithelial markers. The main disadvantage lies in the fact that cells undergoing EMT or with a mesenchymal phenotype might thus be missed. Only a few markers useful in the isolation of CTCs with a mesenchymal phenotype have been evaluated (Table 1). In the past ten years the number of assays to detect and characterize CTCs has increased steadily. All techniques have in common the fact that, due to the low frequency of the isolated tumor cells, they have to be extremely sensitive. In several cases the first step is the enrichment of tumor cells [57]. The choice of enrichment and characterization steps depending on the markers analyzed (especially EpCAM) is crucial to allow as well as to limit the detection of cells undergoing EMT or not. A short perception of enrichment and detection methods in regard to EMT and stem cell markers, some of them commercially available, will be given in the following. These methods are summarized in Table 2.

One way to enrich disseminated tumor cells is density gradient centrifugation. Mononuclear cells are isolated using Ficoll and are subsequently spun on glass slides. Visualization of the tumor cells beside the leukocytes is effected by means of immunocytochemistry. Due to the lack of a general marker, tumor cells are characterized as epithelial cells which are positive, among others, for EpCAM or cytokeratins [58]. Theodoropoulos et al. could identify CTCs with a putative stem cell-like phenotype in the blood of metastatic breast 
TABLE 1: CTC detection and characterization markers.

\begin{tabular}{|c|c|c|c|c|c|}
\hline Marker & Reference & $\begin{array}{l}\text { CTC detection or } \\
\text { enrichment marker }\end{array}$ & $\begin{array}{c}\text { Epithelial } \\
\text { marker }\end{array}$ & $\begin{array}{c}\text { Mesenchymal } \\
\text { marker }\end{array}$ & $\begin{array}{c}\text { Stem cell } \\
\text { marker }\end{array}$ \\
\hline Akt2 & {$[17,19,20]$} & & & $\mathrm{x}$ & \\
\hline ALDH1 & {$[17-20,59,64,77,78]$} & & & & $\mathrm{x}$ \\
\hline Bmil & {$[19]$} & & & & $\mathrm{x}$ \\
\hline CD133 & {$[18]$} & & & & $\mathrm{x}$ \\
\hline $\mathrm{CD} 24$ & {$[18,59,77]$} & & & & $\mathrm{x}$ \\
\hline CD44 & {$[18,19,59,62,77]$} & & & & $\mathrm{x}$ \\
\hline Cytokeratins 8, 18, 19 & {$[24,61]$} & $\mathrm{x}$ & $\mathrm{x}$ & & \\
\hline E-cadherin (Cadherin 1) & {$[69]$} & & $\mathrm{x}$ & & \\
\hline EGFR & {$[69]$} & $\mathrm{x}$ & $\mathrm{x}$ & & \\
\hline EpCAM (GA733-2) & {$[24,58,60,61,65,69]$} & $\mathrm{x}$ & $\mathrm{x}$ & & \\
\hline Fibronectin 1 & {$[69,78]$} & & & $\mathrm{x}$ & \\
\hline FoxC2 & {$[54,74]$} & & & $\mathrm{x}$ & \\
\hline HER2 & {$[60,65,69]$} & $\mathrm{x}$ & $\mathrm{x}$ & & \\
\hline MUC1 & {$[60,65]$} & $\mathrm{x}$ & $\mathrm{x}$ & & \\
\hline $\mathrm{N}$-cadherin (Cadherin 2) & {$[69,75]$} & & & $\mathrm{x}$ & \\
\hline pan-Cytokeratin & {$[59,69]$} & & $\mathrm{x}$ & & \\
\hline PI3K & {$[17,19,20]$} & & & $\mathrm{x}$ & \\
\hline SERPINE1/PAI1 & {$[69]$} & & & $\mathrm{x}$ & \\
\hline SLUG & {$[54,74]$} & & & $\mathrm{x}$ & \\
\hline SNAIL 1 & {$[18,54,74,77]$} & & & $\mathrm{x}$ & \\
\hline TG2 & {$[18]$} & & & $\mathrm{x}$ & \\
\hline TWIST 1 & {$[17-20,54,74,76,77]$} & & & $\mathrm{x}$ & \\
\hline Vimentin & {$[75,76,78]$} & & & $\mathrm{x}$ & \\
\hline ZEB1 & {$[18,54,74]$} & & & $\mathrm{x}$ & \\
\hline ZEB2 & {$[54]$} & & & $\mathrm{x}$ & \\
\hline
\end{tabular}

cancer patients using either cytokeratin, CD44, and CD24 or cytokeratin, ALDH1, and CD24 after density gradient centrifugation [59].

Another way to enrich CTCs is to label the cells with specific antibodies which are conjugated with magnetic particles. There are several tests commercially available which are based on the immunomagnetic enrichment of epithelial markers, especially EpCAM $[24,60]$, therefore limiting the possibilities to detect mesenchymal tumor cells which have undergone EMT. They differ in the subsequent characterization of the CTCs: commonly used techniques are the antibody-based detection of specific markers on the protein level and also on the RNA level using RT-PCR.

The semiautomatic CellSearch system (Janssen Diagnostics, Raritan, NJ, USA) which has been approved by the FDA is based on an immunomagnetic enrichment of epithelial cells using EpCAM-specific antibodies coated with magnetic beads. CTCs are quantified and further characterized by immunofluorescence detecting cytokeratins 8, 18, and 19 and CD45 to exclude leucocytes as well as staining of the nuclei (DAPI) [24, 61]. Additional staining of CD44 could be shown by Lowes et al. [62]. Using the CellSearch Profile Kit which consists only of the immunomagnetic enrichment step of EpCAM+ cells without further characterization allows the individual subsequent characterization of the CTC, using among others ALDH1 [63, 64].

Additional assays are commercially available to detect CTCs based on the analysis of the expression levels of epithelial or tumor-specific genes, where applicable with a preceding enrichment step. In case of the AdnaTest Breast Cancer (AdnaGen GmbH, Langenhagen, Germany) this enrichment step is performed using magnetic beads which are coated with EpCAM- and MUC1-specific antibodies. Subsequent RT-PCR allows the quantitative analysis of the expression levels of MUC1, GA733-2, and HER2 [60, 65, 66]. The additional characterization of the CTCs is effected by means of detection of the EMT and stem cell markers TWIST, Akt2, PI3K, and ALDH1, respectively [17, 20].

There are several approaches to enrich CTCs using special chips combining microfluidics and immobilization of CTCs by binding of specific antibodies (e.g., CTC-chip, Herringbone Chip) [67, 68]. The latter chip was used by Yu et al. to establish an RNA in situ hybridization assay to detect and quantify CTCs with either an epithelial or mesenchymal phenotype or with a phenotype in between (partial EMT). The expression levels of seven pooled epithelial transcripts (EpCAM; cytokeratins 5, 7, 8, 18, and 19 and cadherin 1) and three pooled mesenchymal transcripts (SERPINE1/PAI1, 
TABLE 2: Detection and characterization methods of CTCs.

\begin{tabular}{|c|c|c|c|c|}
\hline Method & Reference & Based on & Detection marker & Characterization marker \\
\hline AdnaTest Breast Cancer & {$[60,65,66]$} & PCR & EpCAM, MUC1 & MUC1, GA733-2, HER2 \\
\hline AdnaTest EMT-1/stem cell & {$[17,20]$} & PCR & EpCAM, MUC1 & TWIST, Akt2, PI3K, ALDH1 \\
\hline CellSearch CTC Kit & {$[24,61,62]$} & Antibody & EpCAM & $\begin{array}{c}\text { CK 8, CK 18, CK 19, CD45, DAPI, HER2, } \\
\text { EGFR, CD44 }\end{array}$ \\
\hline CellSearch Profile Kit & {$[63,64]$} & Antibody & EpCAM & To be determined; for example, ALDH1 \\
\hline CTC-Chip & [67] & Antibody & EpCAM & Cytokeratin, CD45, DAPI \\
\hline Ficoll/immunocytochemistry & {$[58,59,73,79]$} & Antibody & $\begin{array}{l}\text { To be determined; for example, } \\
\text { EpCAM, Cytokeratin }\end{array}$ & $\begin{array}{l}\text { To be determined; for example, CD44, } \\
\text { CD24, ALDH1 }\end{array}$ \\
\hline Filtration & {$[70,71]$} & Filtration & $\begin{array}{l}\text { To be determined; for example, } \\
\text { CK 8, CK 18, CK 19, CD } 45\end{array}$ & To be determined \\
\hline Flow cytometry & {$[80]$} & Antibody & EpCAM, ALDH1 & $\mathrm{CD} 44, \mathrm{CD} 24$ \\
\hline Herringbone-chip & {$[68,69]$} & Antibody & EpCAM, HER2, EGFR & $\begin{array}{c}\text { EpCAM, CK 5, CK 7, CK 8, CK 18, CK 19, } \\
\text { cadherin 1, cadherin 2, SERPINE1/PAI1, } \\
\text { fibronectin } 1\end{array}$ \\
\hline
\end{tabular}

cadherin 2, and fibronectin 1) were analyzed to characterize CTCs which were detected by binding at least one of the following antibodies on a herringbone chip: EpCAM, HER2, or EGFR [69].

Another technique to enrich CTC which is solely based on the size of the cells is filtration. Several systems are available, for example, the ISET filter using pores with a diameter of $8 \mu \mathrm{m}$ [70]. The same pore size was used in another study combining Whatman Nuclepore track-etched membranes and immunofluorescent staining of cytokeratins 8, 18, and 19 as well as CD45 to exclude leucocytes [71].

Flow cytometry is another technique which allows an individual characterization of rare cells like CTCs. Using flow cytometry, Giordano et al. could detect a subpopulation of cancer stem cells expressing either ALDH1, CD44, and low amounts of CD24 or ALDH1 and CD133 [18].

Although the majority of assays use EpCAM as detection marker, different markers are currently used to detect and enrich CTC (Table 2). Due to the fact that CTCs change their phenotype during EMT and MET, false negative results can be obtained depending on which detection marker was used. EpCAM-based assays involve the risk that CTC showing a mesenchymal phenotype might be missed.

\section{Can EMT Be Detected in CTCs?}

To date, several methods have been developed to detect isolated tumor cells in peripheral blood and bone marrow of breast cancer patients. Since there is no breast cancer specific marker to identify these cells, most detection assays rely on their epithelial characteristics $[72,73]$. Based on the assumption that the acquisition of a mesenchymal phenotype by a small fraction of tumor cells disseminated from primary tumor represents a crucial step in the metastatic cascade allowing these cells to migrate to their secondary homing sites and build metastasis, it is possible that EMT markers can be detected among the CTCs of breast cancer patients [13]. This hypothesis has been recently confirmed by various studies in both metastatic and early breast cancer [18-20, 20, 74-78]. Mego et al. demonstrated that EMT markers positive CTCs can be detected in up to $26 \%$ of metastatic breast cancer patients. Moreover, a high expression of EMT markers predicted shorter progression free survival in these patients [77]. Aktas et al. showed in their trial on 39 metastatic breast cancer patients that EMT markers, such as TWIST1, Akt2, and $\mathrm{PI} 3 \mathrm{~K} \alpha$, can be codetected in up to $62 \%$ of CTC positive blood samples; EMT markers were more likely to be found in patients resistant to therapy, suggesting increased invasiveness of tumor cells undergoing this process. Interestingly, cells undergoing EMT have also been detected in the blood of $7 \%$ of patients negative for CTCs [20]. Similar findings in primary breast cancer were presented by Kasimir-Bauer et al.; EMT markers could be detected in $72 \%$ of CTC positive and $18 \%$ of CTC negative patients, respectively [17]. Raimondi et al. demonstrated the expression of EMT markers (e.g., vimentin, fibronectin) in up to $38 \%$ of breast cancer patients tested by the standard definition as CTC negative [78]. These findings suggest that, in addition to CTCs expressing epithelial antigens, a fraction of CTCs with exclusively mesenchymal phenotype could exist and thus remain undetectable for assays based on epithelial character of these cells. However, due to the methodology, morphological features of the cells were not evaluated in these trials and false positive results cannot be excluded $[17,20]$. In this regard, CTCs coexpressing mesenchymal and epithelial markers have been visualized in three other studies in breast cancer patients confirming that both kinds of markers can be expressed in the same cell $[69,75,76]$. Additionally, in the analysis by Armstrong et al. vimentinpositive CTCs were detected in peripheral blood of metastatic breast cancer patients while paired metastases from the same patients were shown to be negative for this marker [75]. This suggests a reversibility of the EMT process once tumor cells reach their destination resembling the phenomenon of epithelial plasticity known from embryonic development [48]. Available literature on EMT in CTCs of breast cancer patients is summarized in Table 3. 
TABLE 3: EMT markers in CTC of breast cancer patients.

\begin{tabular}{|c|c|c|c|c|c|}
\hline Author & Year & $N$ & Method & EMT marker & Expression rate in CTC \\
\hline Kasimir-Bauer et al. [17] & 2012 & $502^{1}$ & RT-PCR & $\begin{array}{c}\text { TWIST1, Akt2 } \\
\text { PI3K } \alpha\end{array}$ & $72 \%^{3, *}, 18 \%^{4, *}$ \\
\hline Giordano et al. [18] & 2012 & $28^{2}$ & RT-PCR & $\begin{array}{c}\text { TWIST1 } \\
\text { SNAIL1 } \\
\text { ZEB1 } \\
\text { TG2 }\end{array}$ & $88 \%{ }^{*}$ \\
\hline Barriere et al. [19] & 2012 & $24^{1}$ & RT-PCR & $\begin{array}{l}\text { TWIST1 } \\
\text { Akt2 } \\
\text { PI3K } \alpha\end{array}$ & $\begin{array}{l}13 \% \\
13 \% \\
67 \%\end{array}$ \\
\hline Mego et al. [77] & 2012 & $21^{2}$ & RT-PCR & $\begin{array}{l}\text { TWIST1 } \\
\text { SNAIL1 }\end{array}$ & $\begin{array}{l}26 \% \\
21 \%\end{array}$ \\
\hline Armstrong et al. [75] & 2011 & $16^{2}$ & IFC & $\begin{array}{c}\text { Vimentin } \\
\text { N-cadherin }\end{array}$ & $\begin{array}{l}70 \% \\
67 \%\end{array}$ \\
\hline Kallergi et al. [76] & 2011 & $50^{1,2}$ & IFC & $\begin{array}{c}\text { TWIST1 } \\
\text { Vimentin }\end{array}$ & $\begin{array}{l}73 \%^{1}, 100 \%^{2} \\
77 \%^{1}, 100 \%^{2}\end{array}$ \\
\hline Mego et al. [74] & 2011 & $52^{1}$ & RT-PCR & $\begin{array}{c}\text { TWIST1 } \\
\text { SNAIL1 } \\
\text { SLUG } \\
\text { ZEB1 } \\
\text { FoxC2 }\end{array}$ & $15,4 \%^{*}$ \\
\hline Raimondi et al. [78] & 2011 & $92^{1,2}$ & RT-PCR & $\begin{array}{l}\text { Vimentin } \\
\text { Fibronectin }\end{array}$ & $\begin{array}{l}28 \%^{3}, 38 \%^{4} \\
18 \%^{3}, 35 \%^{4}\end{array}$ \\
\hline Aktas et al. [20] & 2009 & $39^{2}$ & RT-PCR & $\begin{array}{c}\text { TWIST1 } \\
\text { Akt2 } \\
\text { PI3K } \alpha\end{array}$ & $62 \%^{3, *}, 7 \%^{4, *}$ \\
\hline
\end{tabular}

${ }^{1}$ Primary breast cancer, ${ }^{2}$ metastatic breast cancer, ${ }^{3} \mathrm{CTC}$ positive group, ${ }^{4} \mathrm{CTC}$ negative group; ${ }^{*}$ at least one EMT marker was expressed, PFS: progression free survival.

\section{Are CTCs Cancer Stem Cells?}

One recently discussed hypothesis indicates that tumor progression and metastatic spread can be traced to a small fraction of tumor cells with stem cell-like characteristics [81, 82]. These cancer stem cells have been identified in breast cancer tissue and were shown to be associated with tumors of aggressive behavior [83]. Assuming that CSCs are responsible for tumor cell dissemination and further metastasis, it seems likely that putative stem cell-like features should be found among tumor cells disseminated from primary tumor. This hypothesis has been confirmed by several researchers [17-20, 77-79]. As reported by Balic et al., most disseminated tumor cells in bone marrow of breast cancer patients presented with $\mathrm{CD} 44^{+} / \mathrm{CD} 24^{-/ \text {low }}$ phenotype [79]. Moreover, it has been shown that DTCs with $\mathrm{CD} 44^{+} / \mathrm{CD} 24^{-/ \text {low }}$ phenotype are associated with increased prevalence of metastases and with tumors characterized by aggressive biology [80, 84].

According to recent data both stem cell and EMT markers are frequently coexpressed in CTCs of breast cancer patients $[18,77]$. These findings support the theory that EMT generates a cell population with stem cell-like features, a phenomenon that has been confirmed by numerous experimental trials $[15,85]$. CTCs presenting stem celllike characteristics have been found in both primary and metastatic breast cancer. In a recent study by Kasimir-Bauer et al. on 502 primary breast cancer patients $46 \%$ of CTC positive and $5 \%$ of CTC negative blood samples were positive for ALDH1, a common stem cell marker [17]. Similar findings have been shown by Aktas et al. in the metastatic situation. Moreover, a presence of stem cell-like CTCs in peripheral blood of breast cancer patients was shown to be associated with therapy resistance; stem cell markers or EMT factors or both were detected in 74\% (25/34) of nonresponders and in $10 \%(2 / 21)$ of patients who responded to systemic treatment [20]. In the trial by Raimondi et al. an overexpression of stem cell markers in CTCs was correlated with advanced stage of disease [78]. Cancer stem cells are currently believed to be the cause of therapy resistance and treatment failure in breast cancer [86]. Data on stem cells markers in CTC of breast cancer patients are summarized in Table 4.

\section{Therapeutic Consequences}

To date, systemic therapies target either highly proliferative tumor cells (cytotoxic therapy) or cells with a specific phenotype (e.g., HER2-targeted treatment). However, such therapies are not able to identify cells that act as a source for subsequent metastasis in a selective manner. Tumor cells with putative stem cell-like expression profile are assumed to enter the blood circulation early in the course of disease and might elude therapy precisely because of their stem cell character 
TABLE 4: Stem cell markers in CTC of breast cancer patients.

\begin{tabular}{|c|c|c|c|c|c|}
\hline Author & Year & $N$ & Method & $\begin{array}{l}\text { Stem cell } \\
\text { marker }\end{array}$ & Expression rate in CTC \\
\hline Kasimir-Bauer et al. [17] & 2012 & $502^{1}$ & RT-PCR & ALDH1 & $46 \%^{3}, 5 \%^{4}$ \\
\hline Giordano et al. [18] & 2012 & $28^{2}$ & Flow cytometry & $\begin{array}{c}\text { ALDH } \\
\mathrm{CD} 44^{+} / \mathrm{CD} 24^{\text {low }}\end{array}$ & $\begin{array}{c}0.1 \% \\
3 \%^{3, *}, 49 \%^{4, *}\end{array}$ \\
\hline Barriere et al. [19] & 2012 & $24^{1}$ & RT-PCR & $\begin{array}{c}\text { ALDH1 } \\
\text { CD44 } \\
\text { Bmil }\end{array}$ & $\begin{array}{c}54 \% \\
67 \%^{* *} \\
33 \%^{* *}\end{array}$ \\
\hline Mego et al. [77] & 2012 & $17^{2}$ & Flow cytometry & $\begin{array}{c}\text { ALDH } \\
\mathrm{CD} 44^{+} / \mathrm{CD} 24^{\text {low }}\end{array}$ & n. d. \\
\hline Raimondi et al. [78] & 2011 & $61^{1,2}$ & RT-PCR & ALDH1 & $46 \%$ \\
\hline Aktas et al. [20] & 2009 & $39^{2}$ & RT-PCR & ALDH1 & $69 \%^{3, *}, 14 \%^{4, *}$ \\
\hline Theodoropoulos et al. [59] & 2010 & $30^{2}$ & IFC & $\begin{array}{c}\text { ALDH1 } \\
\mathrm{CD}^{2} 4^{+} / \mathrm{CD} 24^{\text {low }}\end{array}$ & $\begin{array}{l}18 \% \\
35 \%\end{array}$ \\
\hline
\end{tabular}

${ }^{1}$ Primary breast cancer, ${ }^{2}$ metastatic breast cancer, ${ }^{3} \mathrm{CTC}$ positive group, ${ }^{4} \mathrm{CTC}$ negative group; ${ }^{*}$ among ALDH positive cells, ${ }^{* *}$ among EMT or ALDH1 positive cells, n. d.: not done, IFC: immunofluorescence.

$[20,75]$. Hypothetically, specific elimination of these cells could prevent the colonization of secondary homing sites and metastasis formation. Thus, the potential existence of a stem cell-like cancer cell might lead to a paradigm shift in oncologic treatment.

Detection and characterization of CTCs have become an important focus of oncologic research; several clinical trials have been initiated during the last decade that evaluate not only CTCs within accessory translational projects, but also ones that focus exclusively on CTCs and stratify therapy according to CTC levels [87]. Most of these trials (e.g., SWOG0500, CirCe01, TREAT CTC, and DETECT III and IV) are based on immunocytochemical detection of CTCs using the FDA-approved CellSearch system (Veridex, Warren, NJ, USA), a semiautomated antibody-based quantitative technique [88]. Since CTCs are enriched by immunomagnetic beads linked with anti-EpCAM antibodies and detected using antibodies against epithelial antigens, loss of epithelial markers during EMT could make these cells "invisible" to the assay and possibly influence treatment decisions [78, 89]. Gorges et al. reported that use of EpCAMbased enrichment techniques may lead to failure in CTC detection; in an animal based model EpCAM-based AdnaTest failed to detect CTCs despite clinically apparent metastasis. However, CTCs could be detected by PCR without the enrichment step [89]. Recently, antibody-based therapies against tumor cells expressing epithelial markers have been introduced in the treatment of cancer of epithelial origin. Catumaxomab, a trifunctional antibody directed against EpCAM, is a potent therapeutic agent for malignant ascites in EpCAM-positive advanced cancer (e.g., ovarian cancer) [90, 91]. Since EMT involves at least temporary downregulation of EpCAM expression, it might influence the efficacy of EpCAM-directed therapy on tumor cells undergoing EMT.

Therefore, signaling pathways involved in EMT and responsible for the formation of CSCs represent potential targets for future treatment regimens, and drugs inhibiting these pathways are being tested in preclinical and clinical trials [92]. In this regard everolimus (RAD001), an oral inhibitor of PI3K/Akt/mTOR pathway, was shown to inhibit cancer stem cells in vitro and in vivo and demonstrated potential effectivity in treatment of breast cancer cells resistant to standard therapy possibly through this mechanism[93-95]. These data are in accordance with clinical results; in a phase II study RAD001 was shown to restore sensitivity to tamoxifen in metastatic breast cancer patients with endocrine resistance improving the clinical benefit rate at six months in these patients [96]. A phase III BOLERO-2 trial demonstrated a 6month improvement in progression-free survival in patients with resistance to nonsteroidal aromatase inhibitor treated with everolimus in combination with exemestane versus exemestane alone [97]. Everolimus is currently being evaluated for its potential to overcome trastuzumab resistance as well. A phase III BOLERO-1 trial compares trastuzumab and paclitaxel with and without everolimus, while the phase III BOLERO-3 trial compares trastuzumab and vinorelbine with and without everolimus.

Hedgehog, Notch, and Wnt represent further signaling pathways involved in formation of breast cancer stem cells [98-100]. Since the expression of Notch ligands has been demonstrated to be significantly elevated in triple negative breast cancer, Notch has become a promising target in breast cancer treatment [101]. In this context blocking of Notch by $\gamma$-secretase inhibitors (GSIs) has been the most extensively used approach. GSIs were shown to induce apoptosis and decrease proliferation in breast cancer cell lines and to eliminate breast cancer stem cells in vitro [102, 103]. GSIs like MK-0752 or RO4929097 have been tested in phase I and II clinical trials in primary and metastatic breast cancer providing early clinical evidence of effectiveness for these agents in breast cancer therapy [104, 105]. A phase I study analyzes RO4929097 in combination with Hedgehog pathway antagonist vismodegib in metastatic breast cancer patients [106]. Vismodegib, established in the therapy of advanced basal cell carcinoma, was also shown to inhibit tumor cell growth in tamoxifen resistant breast cancer in vivo and in vitro [107]. Furthermore, PKF118-310 an inhibitor of Wnt signaling pathway was recently reported to eradicate breast 
cancer stem cells in a mouse model overexpressing HER2, thus also representing a potential drug candidate for the treatment of breast cancer [108].

An additional agent that was demonstrated to be effective against breast cancer stem cells is all transretinoic acid (ATRA). In a recent experimental approach, ATRA was able to eliminate breast cancer cells that gained CSC properties, suggesting its effectiveness in cancer resistant to conventional oncologic therapies [109]. However, ATRA has to date performed poorly in clinical trials; in a pilot phase II study 17 metastatic or recurrent breast cancer patients were treated with ATRA in combination with paclitaxel showing time to progression and survival rates similar to those reported for paclitaxel alone [110].

Another promising drug candidate in this context is salinomycin, which was shown to inhibit tumor growth in mice by eradicating breast cancer stem cells [111]. Recent preclinical trials demonstrated that salinomycin is particularly effective against cancer growth in combination with conventional chemotherapeutics, supporting the postulation that targeting different cell populations is essential in cancer therapy [112].

\section{Conclusions}

Multiple studies have shown that single tumor cells undergo transdifferentiation which enables intravasation; this important step of metastatic cascade is termed epithelial-mesenchymal transition. Through EMT, circulating tumor cells downregulate epithelial antigens and cell-to-cell adhesion and thus enhance their motility and invasive potential. Cells that undergo EMT seem to gain stem cell-like properties; such cells represent a small fraction of tumor cells capable of self-renewal and highly resistant to cytotoxic treatment. Since the majority of CTC detection systems are based on the presence of epithelial markers, tumor cells that have undergone EMT might elude classical detection methods, which may lead to false-negative results.

\section{Abbreviations}

ALDH: Aldehyde dehydrogenase

CSC: $\quad$ Cancer stem cell

CTC: Circulating tumor cell

DAPI: $\quad 4^{\prime}, 6$-Diamidino-2-phenylindole

DTC: Disseminated tumor cell

EGF: Epidermal growth factor

EGFR: Epidermal growth factor receptor

EMT: Epithelial-mesenchymal transition

EpCAM: Epithelial cell adhesion molecule

GA733-2: Gastrointestinal tumor-associated antigen

HER2: Human epidermal growth receptor 2

MET: Mesenchymal epithelial transition

mTOR: Mammalian target of rapamycin

MUC1: Mucin 1

PCR: $\quad$ Polymerase chain reaction

PI3K: $\quad$ Phosphoinositide 3-kinase

TGF $\beta$ : Transforming growth factor beta.

\section{Conflict of Interests}

The authors declare that there is no conflict of interests regarding the publication of this paper.

\section{References}

[1] S. Braun, F. D. Vogl, B. Naume et al., "A pooled analysis of bone marrow micrometastasis in breast cancer," The New England Journal of Medicine, vol. 353, no. 8, pp. 793-802, 2005.

[2] B. Rack, C. Schindlbeck, A. Schneeweiss et al., "Prognostic relevance of circulating tumor cells in the peripheral blood of primary breast cancer patients," in Proceedings of the 33rd Annual San Antonio Breast Cancer Symposium, pp. S6-S5, 2010.

[3] W. Janni, F. D. Vogl, G. Wiedswang et al., "Persistence of disseminated tumor cells in the bone marrow of breast cancer patients predicts increased risk for relapse-a European pooled analysis," Clinical Cancer Research, vol. 17, no. 9, pp. 2967-2976, 2011.

[4] N. Xenidis, M. Ignatiadis, S. Apostolaki et al., "Cytokeratin19 mRNA-positive circulating tumor cells after adjuvant chemotherapy in patients with early breast cancer," Journal of Clinical Oncology, vol. 27, no. 13, pp. 2177-2184, 2009.

[5] B. K. Rack, C. Schindlbeck, U. Andergassen et al., "Use of circulating tumor cells (CTC) in peripheral blood of breast cancer patients before and after adjuvant chemotherapy to predict risk for relapse: the SUCCESS trial," Journal of Clinical Oncology, vol. 28, p. 15s, abstract 1003, 2010.

[6] I. J. Fidler, "Metastasis: guantitative analysis of distribution and fate of tumor embolilabeled with 125 I-5-iodo-2' deoxyuridine," Journal of the National Cancer Institute, vol. 45, no. 4, pp. 773-782, 1970.

[7] S. M. Frisch and R. A. Screaton, "Anoikis mechanisms," Current Opinion in Cell Biology, vol. 13, no. 5, pp. 555-562, 2001.

[8] M. D. Cameron, E. E. Schmidt, N. Kerkvliet et al., "Temporal progression of metastasis in lung: cell survival, dormancy, and location dependence of metastatic inefficiency," Cancer Research, vol. 60, no. 9, pp. 2541-2546, 2000.

[9] Y. Kienast, L. Von Baumgarten, M. Fuhrmann et al., "Real-time imaging reveals the single steps of brain metastasis formation," Nature Medicine, vol. 16, no. 1, pp. 116-122, 2010.

[10] J. P. Sleeman, I. Nazarenko, and W. Thiele, "Do all roads lead to Rome? Routes to metastasis development," International Journal of Cancer, vol. 128, no. 11, pp. 2511-2526, 2011.

[11] G. Méhes, A. Witt, E. Kubista, and P. F. Ambros, "Circulating breast cancer cells rre frequently apoptotic," American Journal of Pathology, vol. 159, no. 1, pp. 17-20, 2001.

[12] C. J. Larson, J. G. Moreno, K. J. Pienta et al., "Apoptosis of circulating tumor cells in prostate cancer patients," Cytometry Part A, vol. 62, no. 1, pp. 46-53, 2004.

[13] J. P. Their, "Epithelial-mesenchymal transitions in tumor progression," Nature Reviews Cancer, vol. 2, no. 6, pp. 442-454, 2002.

[14] M. Guarino, "Epithelial-mesenchymal transition and tumour invasion," International Journal of Biochemistry and Cell Biology, vol. 39, no. 12, pp. 2153-2160, 2007.

[15] S. A. Mani, W. Guo, M.-J. Liao et al., "The epithelialmesenchymal transition generates cells with properties of stem cells," Cell, vol. 133, no. 4, pp. 704-715, 2008.

[16] T. Brabletz, "EMT and MET in metastasis: where are the cancer stem cells?” Cancer Cell, vol. 22, no. 6, pp. 699-701, 2012. 
[17] S. Kasimir-Bauer, O. Hoffmann, D. Wallwiener, R. Kimmig, and T. Fehm, "Expression of stem cell and epithelial-mesenchymal transition markers in primary breast cancer patients with circulating tumor cells," Breast Cancer Researchearch, vol. 14, no. 1, article R15, 2012.

[18] A. Giordano, H. Gao, S. Anfossi et al., "Epithelial-mesenchymal transition and stem cell markers in patients with HER2-positive metastatic breast cancer," Molecular Cancer Therapeutics, vol. 11, no. 11, pp. 2526-2534, 2012.

[19] G. Barriere, A. Riouallon, J. Renaudie, M. Tartary, and P. R. Michel, "Mesenchymal and stemness circulating tumor cells in early breast cancer diagnosis," BMC Cancer, vol. 12, p. 114, 2012.

[20] B. Aktas, M. Tewes, T. Fehm, S. Hauch, R. Kimmig, and S. Kasimir-Bauer, "Stem cell and epithelial-mesenchymal transition markers are frequently overexpressed in circulating tumor cells of metastatic breast cancer patients," Breast Cancer Researchearch, vol. 11, no. 4, article R46, 2009.

[21] N. Eisemann, A. Waldmann, and A. Katalinic, "Epidemiology of breast cancer-current figures and trends," Geburtsh Frauenheilk, vol. 73, no. 2, pp. 130-135, 2013.

[22] C. Melcher, C. Scholz, B. Jäger, C. Hagenbeck, B. Rack, and W. Janni, "Breast cancer: state of the art and new findings," Geburtshilfe und Frauenheilkunde, vol. 72, no. 3, pp. 215-224, 2012.

[23] C. A. Klein, "Parallel progression of primary tumours and metastases," Nature Reviews Cancer, vol. 9, no. 4, pp. 302-312, 2009.

[24] M. Cristofanilli, G. T. Budd, M. J. Ellis et al., "Circulating tumor cells, disease progression, and survival in metastatic breast cancer," The New England Journal of Medicine, vol. 351, no. 8, pp. 781-791, 2004.

[25] B. K. Rack, C. Schindlbeck, U. Andergassen et al., "Use of circulating tumor cells (CTC) in peripheral blood of breast cancer patients before and after adjuvant chemotherapy to predict risk for relapse: the SUCCESS trial," Journal of Clinical Oncology, vol. 28, p. 15s, abstract 1003, 2010.

[26] H. Kolberg, D. Luftner, M. P. Lux et al., "Breast cancer 2012new aspects," Geburtshilfe und Frauenheilkunde, vol. 72, no. 7, pp. 602-615, 2012.

[27] B. Franken, M. R. de Groot, W. J. Mastboom et al., "Circulating tumor cells, disease recurrence and survival in newly diagnosed breast cancer," Breast Cancer Research, vol. 14, no. 5, p. R133, 2012.

[28] T. J. Molloy, A. J. Bosma, L. O. Baumbusch et al., "The prognostic significance of tumour cell detection in the peripheral blood versus the bone marrow in 733 early-stage breast cancer patients," Breast Cancer Researchearch, vol. 13, no. 3, article R61, 2011.

[29] F.-C. Bidard, C. Mathiot, S. Delaloge et al., "Single circulating tumor cell detection and overall survival in nonmetastatic breast cancer," Annals of Oncology, vol. 21, no. 4, pp. 729-733, 2009.

[30] J.-Y. Pierga, F.-C. Bidard, C. Mathiot et al., "Circulating tumor cell detection predicts early metastatic relapse after neoadjuvant chemotherapy in large operable and locally advanced breast cancer in a phase II randomized trial," Clinical Cancer Research, vol. 14, no. 21, pp. 7004-7010, 2008.

[31] I. H. Benoy, H. Elst, M. Philips et al., "Real-time RT-PCR detection of disseminated tumour cells in bone marrow has superior prognostic significance in comparison with circulating tumour cells in patients with breast cancer," British Journal of Cancer, vol. 94, no. 5, pp. 672-680, 2006.
[32] Y. Nieto, W. A. Franklin, R. B. Jones et al., "Prognostic significance of occult tumor cells in the apheresis products of patients with advanced breast cancer receiving high-dose chemotherapy and autologous hematopoietic progenitor cell support," Biology of Blood and Marrow Transplantation, vol. 10, no. 6, pp. 415-425, 2004.

[33] A. Stathopoulou, I. Vlachonikolis, D. Mavroudis et al., "Molecular detection of cytokeratin-19-positive cells in the peripheral blood of patients with operable breast cancer: evaluation of their prognostic significance," Journal of Clinical Oncology, vol. 20, no. 16, pp. 3404-3412, 2002.

[34] J.-Y. Pierga, T. Petit, T. Delozier et al., "Neoadjuvant bevacizumab, trastuzumab, and chemotherapy for primary inflammatory HER2-positive breast cancer (BEVERLY-2): an openlabel, single-arm phase 2 study," The Lancet Oncology, vol. 13, no. 4, pp. 375-384, 2012.

[35] L. A. Liotta, J. Kleinerman, and G. M. Saidel, "Quantitative relationships of intravascular tumor cells, tumor vessels, and pulmonary metastases following tumor implantation," Cancer Research, vol. 34, no. 5, pp. 997-1004, 1974.

[36] R. R. Mathiesen, E. Borgen, A. Renolen et al., "Persistence of disseminated tumor cells after neoadjuvant treatment for locally advanced breast cancer predicts poor survival," Breast Cancer Research, vol. 14, no. 4, p. R117, 2012.

[37] F. C. Bidard, D. J. Peeters, T. Fehm et al., "Clinical validity of circulating tumour cells in patients with metastatic breast cancer: a pooled analysis of individual patient data," The Lancet Oncology, 2014.

[38] S. Paget, "The distribution of secondary growths in cancer of the breast,” The Lancet, vol. 133, no. 3421, pp. 571-573, 1889.

[39] T. P. Butler and P. M. Gullino, "Quantitation of cell shedding into efferent blood of mammary adenocarcinoma," Cancer Research, vol. 35, no. 3, pp. 512-516, 1975.

[40] I. J. Fidler, "The pathogenesis of cancer metastasis: the "seed and soil" hypothesis revisited," Nature Reviews Cancer, vol. 3, no. 6, pp. 453-458, 2003.

[41] I. J. Fidler and G. Poste, "The "seed and soil" hypothesis revisited," The Lancet Oncology, vol. 9, no. 8, p. 808, 2008.

[42] R. R. Langley and I. J. Fidler, "The seed and soil hypothesis revisited-The role of tumor-stroma interactions in metastasis to different organs," International Journal of Cancer, vol. 128, no. 11, pp. 2527-2535, 2011.

[43] E. S. Lianidou, D. Mavroudis, and V. Georgoulias, "Clinical challenges in the molecular characterization of circulating tumour cells in breast cancer," British Journal of Cancer, vol. 108, no. 12, pp. 2426-2432, 2013.

[44] T. Fehm, V. Müller, B. Aktas et al., "HER2 status of circulating tumor cells in patients with metastatic breast cancer: a prospective, multicenter trial," Breast Cancer Researchearch and Treatment, vol. 124, no. 2, pp. 403-412, 2010.

[45] N. Krawczyk, M. Banys, A. Hartkopf, C. Hagenbeck, C. Melcher, and T. Fehm, "Circulating tumour cells in breast cancer," Ecancermedicalscience, vol. 7, p. 352, 2013.

[46] M. A. Nieto, "Epithelial-mesenchymal transitions in development and disease: old views and new perspectives," International Journal of Developmental Biology, vol. 53, no. 8-10, pp. 1541-1547, 2009.

[47] H. Acloque, M. S. Adams, K. Fishwick, M. Bronner-Fraser, and M. A. Nieto, "Epithelial-mesenchymal transitions: the importance of changing cell state in development and disease," Journal of Clinical Investigation, vol. 119, no. 6, pp. 1438-1449, 2009. 
[48] M. A. Nieto, "Epithelial plasticity: a common theme in embryonic and cancer cells," Science, vol. 342, p. 6159, 2013.

[49] M. Iwano, D. Plieth, T. M. Danoff, C. Xue, H. Okada, and E. G. Neilson, "Evidence that fibroblasts derive from epithelium during tissue fibrosis," Journal of Clinical Investigation, vol. 110, no. 3, pp. 341-350, 2002.

[50] H. Hugo, M. L. Ackland, T. Blick et al., "Epithelial-mesenchymal and mesenchymal-epithelial transitions in carcinoma progression," Journal of Cellular Physiology, vol. 213, no. 2, pp. 374-383, 2007.

[51] D. Yao, C. Dai, and S. Peng, "Mechanism of the mesenchymalepithelial transition and its relationship with metastatic tumor formation," Molecular Cancer Research, vol. 9, no. 12, pp. 16081620, 2011.

[52] Y. L. Chao, C. R. Shepard, and A. Wells, "Breast carcinoma cells re-express E-cadherin during mesenchymal to epithelial reverting transition," Molecular Cancer, vol. 9, article 179, 2010.

[53] T. Imai, A. Horiuchi, T. Shiozawa et al., "Elevated expression of E-cadherin and $\alpha$-, $\beta$-, and $\gamma$-catenins in metastatic lesions compared with primary epithelial ovarian carcinomas," Human Pathology, vol. 35, no. 12, pp. 1469-1476, 2004.

[54] J. P. Thiery, H. Acloque, R. Y. J. Huang, and M. A. Nieto, "Epithelial-mesenchymal transitions in development and disease," Cell, vol. 139, no. 5, pp. 871-890, 2009.

[55] D. Sarrió, S. M. Rodriguez-Pinilla, D. Hardisson, A. Cano, G. Moreno-Bueno, and J. Palacios, "Epithelial-mesenchymal transition in breast cancer relates to the basal-like phenotype," Cancer Research, vol. 68, no. 4, pp. 989-997, 2008.

[56] N. Dumont, M. B. Wilson, Y. G. Crawford, P. A. Reynolds, M. Sigaroudinia, and T. D. Tlsty, "Sustained induction of epithelial to mesenchymal transition activates DNA methylation of genes silenced in basal-like breast cancers," Proceedings of the National Academy of Sciences of the United States of America, vol. 105, no. 39, pp. 14867-14872, 2008.

[57] A. A. Ross, B. W. Cooper, H. M. Lazarus et al., "Detection and viability of tumor cells in peripheral blood stem cell collections from breast cancer patients using immunocytochemical and clonogenic assay techniques," Blood, vol. 82, no. 9, pp. 26052610, 1993.

[58] T. Fehm, A. Sagalowsky, E. Clifford et al., "Cytogenetic evidence that circulating epithelial cells in patients with carcinoma are malignant," Clinical Cancer Research, vol. 8, no. 7, pp. 20732084, 2002.

[59] P. A. Theodoropoulos, H. Polioudaki, S. Agelaki et al., "Circulating tumor cells with a putative stem cell phenotype in peripheral blood of patients with breast cancer," Cancer Letters, vol. 288, no. 1, pp. 99-106, 2010.

[60] T. Fehm, O. Hoffmann, B. Aktas et al., "Detection and characterization of circulating tumor cells in blood of primary breast cancer patients by RT-PCR and comparison to status of bone marrow disseminated cells," Breast Cancer Researchearch, vol. 11, no. 4, article R59, 2009.

[61] C. Cristofanilli, D. F. Hayes, G. T. Budd et al., "Circulating tumor cells: a novel prognostic factor for newly diagnosed metastatic breast cancer," Journal of Clinical Oncology, vol. 23, no. 7, pp. 1420-1430, 2005.

[62] L. E. Lowes, B. D. Hedley, M. Keeney, and A. L. Allan, "Userdefined protein marker assay development for characterization of circulating tumor cells using the CellSearch(R) system," Cytometry Part A, vol. 81, no. 11, pp. 983-995, 2012.
[63] L. M. Flores, D. W. Kindelberger, A. H. Ligon et al., "Improving the yield of circulating tumour cells facilitates molecular characterisation and recognition of discordant HER2 amplification in breast cancer," British Journal of Cancer, vol. 102, no. 10, pp. 1495-1502, 2010.

[64] A. M. Sieuwerts, J. Kraan, J. Bolt-De Vries et al., "Molecular characterization of circulating tumor cells in large quantities of contaminating leukocytes by a multiplex real-time PCR," Breast Cancer Researchearch and Treatment, vol. 118, no. 3, pp. 455468, 2009.

[65] U. Demel, G. P. Tilz, Z. Foeldes-Papp, B. Gutierrez, W. H. Albert, and O. Böcher, "Detection of tumour cells in the peripheral blood of patients with breast cancer. Development of a new sensitive and specific immunomolecular assay," Journal of Experimental and Clinical Cancer Research, vol. 23, no. 3, pp. 465-468, 2004.

[66] S. Lankiewicz, B. G. Rivero, and O. Bócher, "Quantitative realtime RT-PCR of disseminated tumor cells in combination with immunomagnetic cell enrichment," Molecular Biotechnology, vol. 34, no. 1, pp. 15-27, 2006.

[67] S. Nagrath, L. V. Sequist, S. Maheswaran et al., "Isolation of rare circulating tumour cells in cancer patients by microchip technology," Nature, vol. 450, no. 7173, pp. 1235-1239, 2007.

[68] S. L. Stott, C.-H. Hsu, D. I. Tsukrov et al., "Isolation of circulating tumor cells using a microvortex-generating herringbonechip," Proceedings of the National Academy of Sciences of the United States of America, vol. 107, no. 43, pp. 18392-18397, 2010.

[69] M. Yu, A. Bardia, B. S. Wittner et al., "Circulating breast tumor cells exhibit dynamic changes in epithelial and mesenchymal composition," Science, vol. 339, no. 6119, pp. 580-584, 2013.

[70] F. Farace, C. Massard, N. Vimond et al., "A direct comparison of CellSearch and ISET for circulating tumour-cell detection in patients with metastatic carcinomas," British Journal of Cancer, vol. 105, no. 6, pp. 847-853, 2011.

[71] P. Fasching, W. Gumbrecht, T. N. Fehm et al., “4EVER: assessment of circulating tumor cells with a novel, filtration-based method, in a phase IIIb multicenter study for postmenopausal, HER2-negative, estrogen receptor-positive, advanced breast cancer patients," Journal of Clinical Oncology, vol. 31, no. 15, p. 591, 2013.

[72] K. Pantel and K. C, "Alix-panabieres, detection methods of circulating tumor cells," J Thorac Dis, vol. 4, no. 5, pp. 446-447, 2012.

[73] T. Fehm, S. Braun, V. Muller et al., "A concept for the standardized detection of disseminated tumor cells in bone marrow from patients with primary breast cancer and its clinical implementation," Cancer, vol. 107, no. 5, pp. 885-892, 2006.

[74] M. Mego, S. A. Mani, B.-N. Lee et al., "Expression of epithelialmesenchymal transition-inducing transcription factors in primary breast cancer: the effect of neoadjuvant therapy," International Journal of Cancer, vol. 130, no. 4, pp. 808-816, 2012.

[75] A. J. Armstrong, M. S. Marengo, S. Oltean et al., "Circulating tumor cells from patients with advanced prostate and breast cancer display both epithelial and mesenchymal markers," Molecular Cancer Research, vol. 9, no. 8, pp. 997-1007, 2011.

[76] G. Kallergi, M. A. Papadaki, E. Politaki, D. Mavroudis, V. Georgoulias, and S. Agelaki, "Epithelial to mesenchymal transition markers expressed in circulating tumour cells of early and metastatic breast cancer patients," Breast Cancer Researchearch, vol. 13, no. 3, article R59, 2011. 
[77] M. Mego, H. Gao, B. N. Lee et al., "Prognostic value of EMT-circulating tumor cells in metastatic breast cancer patients undergoing high-dose chemotherapy with autologous hematopoietic stem cell transplantation," Journal of Cancer, vol. 3, pp. 369-380, 2012.

[78] C. Raimondi, A. Gradilone, G. Naso et al., "Epithelial-mesenchymal transition and stemness features in circulating tumor cells from breast cancer patients," Breast Cancer Researchearch and Treatment, vol. 130, no. 2, pp. 449-455, 2011.

[79] M. Balic, H. Lin, L. Young et al., "Most early disseminated cancer cells detected in bone marrow of breast cancer patients have a putative breast cancer stem cell phenotype," Clinical Cancer Research, vol. 12, no. 19, pp. 5615-5621, 2006.

[80] J. M. Reuben, B.-N. Lee, H. Gao et al., "Primary breast cancer patients with high risk clinicopathologic features have high percentages of bone marrow epithelial cells with ALDH activity and $\mathrm{CD} 44^{+} \mathrm{CD} 24^{\text {lo }}$ cancer stem cell phenotype," European Journal of Cancer, vol. 47, no. 10, pp. 1527-1536, 2011.

[81] M. Al-Hajj, M. S. Wicha, A. Benito-Hernandez, S. J. Morrison, and M. F. Clarke, "Prospective identification of tumorigenic breast cancer cells," Proceedings of the National Academy of Sciences of the United States of America, vol. 100, no. 7, pp. 39833988, 2003.

[82] T. Reya, S. J. Morrison, M. F. Clarke, and I. L. Weissman, "Stem cells, cancer, and cancer stem cells," Nature, vol. 414, no. 6859, pp. 105-111, 2001.

[83] S. Pece, D. Tosoni, S. Confalonieri et al., "Biological and molecular heterogeneity of breast cancers correlates with their cancer stem cell content," Cell, vol. 140, no. 1, pp. 62-73, 2010.

[84] B. K. Abraham, P. Fritz, M. McClellan, P. Hauptvogel, M. Athelogou, and H. Brauch, "Prevalence of CD44+/CD24-/low cells in breast cancer may not be associated with clinical outcome but may favor distant metastasis," Clinical Cancer Research, vol. 11, no. 3, pp. 1154-1159, 2005.

[85] A.-P. Morel, M. Lièvre, C. Thomas, G. Hinkal, S. Ansieau, and A. Puisieux, "Generation of breast cancer stem cells through epithelial-mesenchymal transition," PLoS ONE, vol. 3, no. 8, Article ID e2888, 2008.

[86] J. Monteiro and R. Fodde, "Cancer stemness and metastasis: therapeutic consequences and perspectives," European Journal of Cancer, vol. 46, no. 7, pp. 1198-1203, 2010.

[87] F. C. Bidard, T. Fehm, M. Ignatiadis et al., "Clinical application of circulating tumor cells in breast cancer: overview of the current interventional trials," Cancer and Metastasis Reviews, vol. 32, no. 1-2, pp. 179-188, 2013.

[88] M. Banys, V. Müller, C. Melcher et al., "Circulating tumor cells in breast cancer," Clinica Chimica Acta, vol. 423, pp. 39-45, 2013.

[89] T. M. Gorges, I. Tinhofer, M. Drosch et al., "Circulating tumour cells escape from EpCAM-based detection due to epithelial-tomesenchymal transition," BMC Cancer, vol. 12, p. 178, 2012.

[90] K. Pietzner, M. Jäger, A. Schoberth et al., "First patient treated with a re-challenge of catumaxomab in recurrent malignant ascites: a case report," Medical Oncology, vol. 29, no. 2, pp. 13911396, 2012.

[91] K. Baumann, J. Pfisterer, P. Wimberger et al., "Intraperitoneal treatment with the trifunctional bispecific antibody Catumaxomab in patients with platinum-resistant epithelial ovarian cancer: a phase IIa study of the AGO Study Group," Gynecologic Oncology, vol. 123, no. 1, pp. 27-32, 2011.

[92] D. Luftner, M. P. Lux, N. Maass et al., "Advances in breast cancer-looking back over the year," Geburtsh Frauenheilk, vol. 72, no. 12, pp. 1117-1129, 2012.
[93] Y. Zhu, X. Zhang, Y. Liu et al., "Antitumor effect of the mTOR inhibitor everolimus in combination with trastuzumab on human breast cancer stem cells in vitro and in vivo," Tumor Biology, vol. 33, no. 5, pp. 1349-1362, 2012.

[94] X. Zhang, S. Zhang, Y. Liu et al., "Effects of the combination of RAD001 and docetaxel on breast cancer stem cells," European Journal of Cancer, vol. 48, no. 10, pp. 1581-1592, 2012.

[95] H. Liu, H. W. Zhang, X. F. Sun et al., "Tamoxifen-resistant breast cancer cells possess cancer stem-like cell properties," Chinese Medical Journal, vol. 126, no. 16, pp. 3030-3034, 2013.

[96] T. Bachelot, C. Bourgier, C. Cropet et al., "Randomized phase II trial of everolimus in combination with tamoxifen in patients with hormone receptor-positive, human epidermal growth factor receptor 2-negative metastatic breast cancer with prior exposure to aromatase inhibitors: a GINECO study," Journal of Clinical Oncology, vol. 30, no. 22, pp. 2718-2724, 2012.

[97] J. Baselga, M. Campone, M. Piccart et al., "Everolimus in postmenopausal hormone-receptor-positive advanced breast cancer," The New England Journal of Medicine, vol. 366, no. 6, pp. 520-529, 2012.

[98] W. Cui, L.-H. Wang, Y.-Y. Wen et al., "Expression and regulation mechanisms of Sonic Hedgehog in breast cancer," Cancer Science, vol. 101, no. 4, pp. 927-933, 2010.

[99] M. Souzaki, M. Kubo, M. Kai et al., "Hedgehog signaling pathway mediates the progression of non-invasive breast cancer to invasive breast cancer," Cancer Science, vol. 102, no. 2, pp. 373381, 2011.

[100] H. Al-Hussaini, D. Subramanyam, M. Reedijk, and S. S. Sridhar, "Notch signaling pathway as a therapeutic target in breast cancer," Molecular Cancer Therapeutics, vol. 10, no. 1, pp. 9-15, 2011.

[101] M. Reedijk, "Notch signaling and breast cancer," Advances in Experimental Medicine and Biology, vol. 727, pp. 241-257, 2012.

[102] S. Rasul, R. Balasubramanian, A. Filipovi, M. J. Slade, E. Yagüe, and R. C. Coombes, "Inhibition of $\gamma$-secretase induces G2M arrest and triggers apoptosis in breast cancer cells," British Journal of Cancer, vol. 100, no. 12, pp. 1879-1888, 2009.

[103] M. Kondratyev, A. Kreso, R. M. Hallett et al., "Gamma-secretase inhibitors target tumor-initiating cells in a mouse model of ERBB2 breast cancer," Oncogene, vol. 31, no. 1, pp. 93-103, 2012.

[104] I. Krop, T. Demuth, T. Guthrie et al., "Phase I pharmacologic and pharmacodynamic study of the gamma secretase (Notch) inhibitor MK-0752 in adult patients with advanced solid tumors," Journal of Clinical Oncology, vol. 30, no. 19, pp. 2307-2313, 2012.

[105] UoM, C., Phase I/II Study of MK-0752 Followed By Docetaxel in Advanced Metastatic Breast Cancer. Clinical Trials.Gov [Internet], National Library of Medicine (US), Bethesda, Md, USA, 2000.

[106] BAKC, I., GDC-0449 and R04929097 in Treating Women With Advanced Breast Cancer. Clinical Trialsgov, National Library of Medicine, Bethesda, Md, USA, 2000.

[107] B. Ramaswamy, Y. Lu, K. Y. Teng et al., "Hedgehog signaling is a novel therapeutic target in tamoxifen-resistant breast cancer aberrantly activated by PI3K/AKT pathway," Cancer Research, vol. 72, no. 19, pp. 5048-5059, 2012.

[108] R. M. Hallett, M. K. Kondratyev, A. O. Giacomelli et al., "Small molecule antagonists of the Wnt/Beta-catenin signaling pathway target breast tumor-initiating cells in a Her2/Neu mouse model of breast cancer," PLoS ONE, vol. 7, no. 3, Article ID e33976, 2012. 
[109] P. Bhat-Nakshatri, C. P. Goswami, S. Badve, G. W. Sledge Jr, and H. Nakshatri, "Identification of FDA-approved drugs targeting breast cancer stem cells along with biomarkers of sensitivity," Scientific Reports, vol. 3, p. 2530, 2013.

[110] M. Bryan, E. D. Pulte, K. C. Toomey et al., "A pilot phase II trial of all-trans retinoic acid (Vesanoid) and paclitaxel (Taxol) in patients with recurrent or metastatic breast cancer," Investigational New Drugs, vol. 29, no. 6, pp. 1482-1487, 2011.

[111] P. B. Gupta, T. T. Onder, G. Jiang et al., "Identification of selective inhibitors of cancer stem cells by high-throughput screening," Cell, vol. 138, no. 4, pp. 645-659, 2009.

[112] Y. Zhang, H. Zhang, X. Wang, J. Wang, X. Zhang, and Q. Zhang, "The eradication of breast cancer and cancer stem cells using octreotide modified paclitaxel active targeting micelles and salinomycin passive targeting micelles," Biomaterials, vol. 33, no. 2, pp. 679-691, 2012 


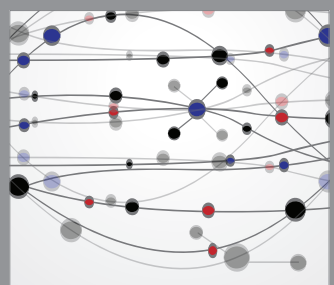

The Scientific World Journal
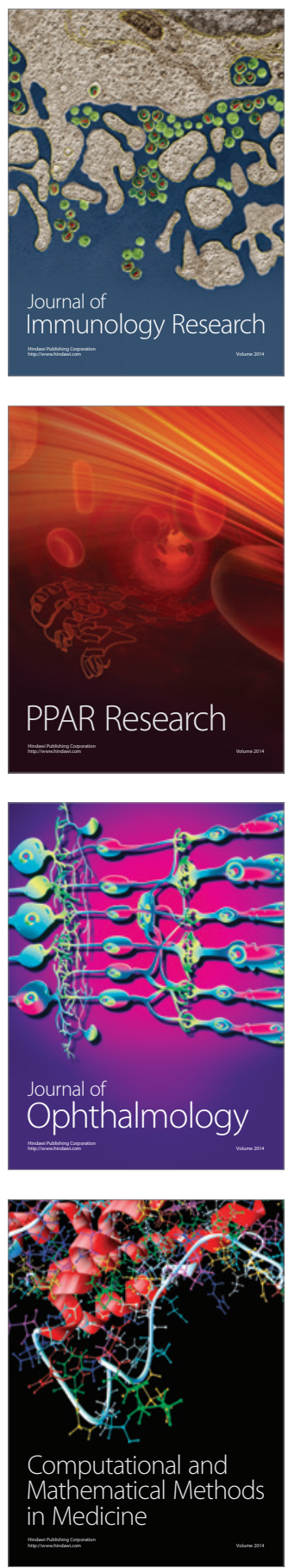

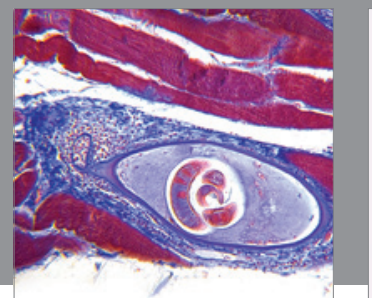

Gastroenterology

Research and Practice
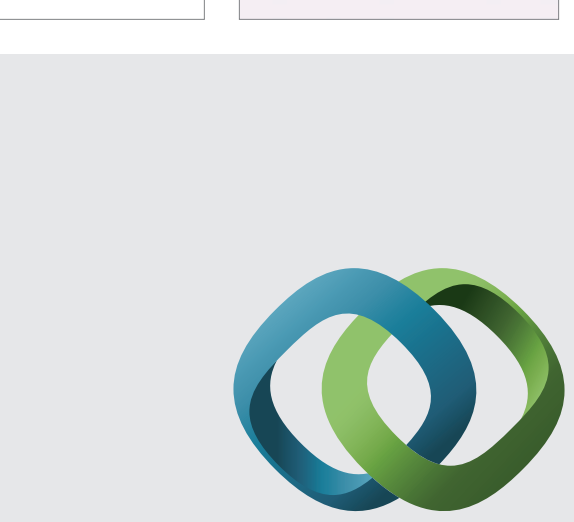

\section{Hindawi}

Submit your manuscripts at

http://www.hindawi.com
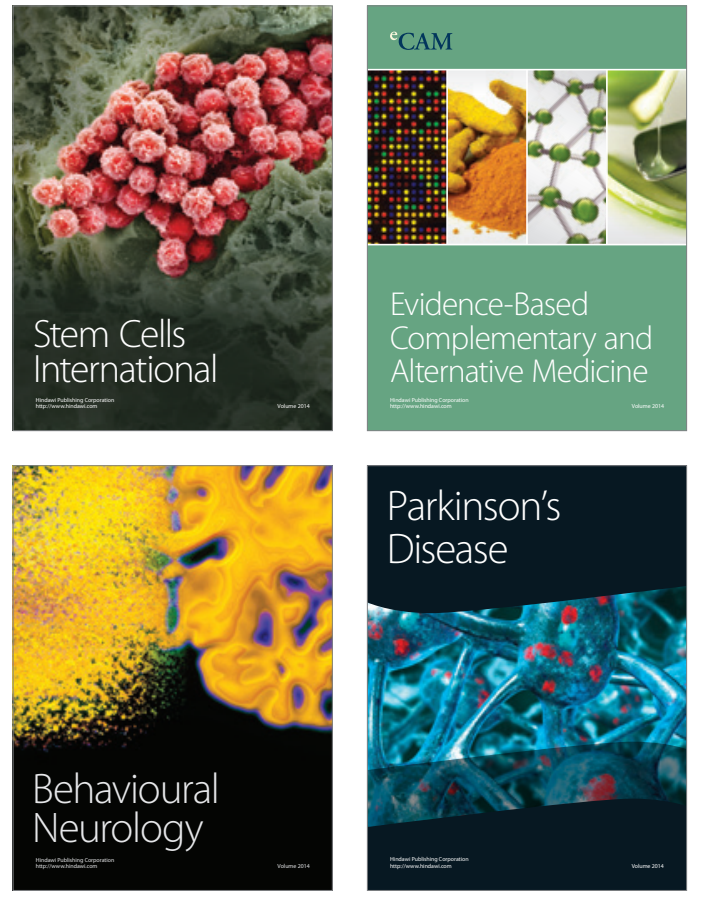
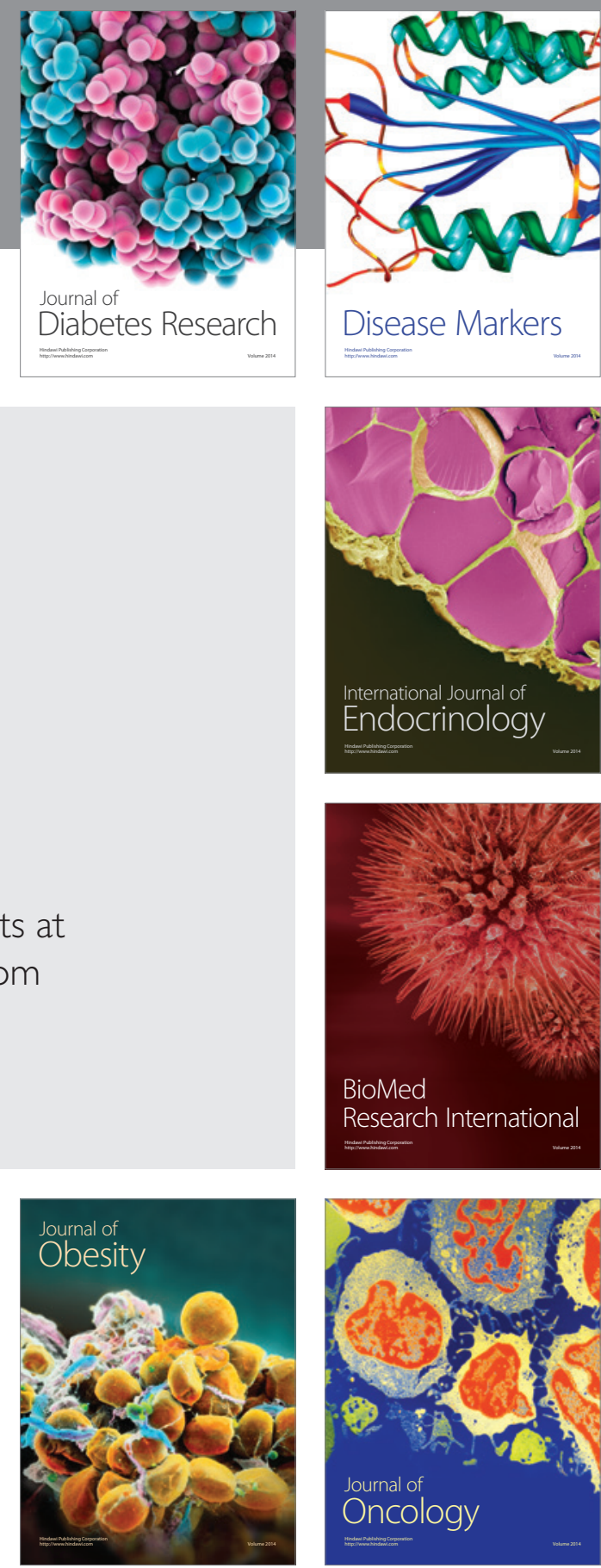

Disease Markers
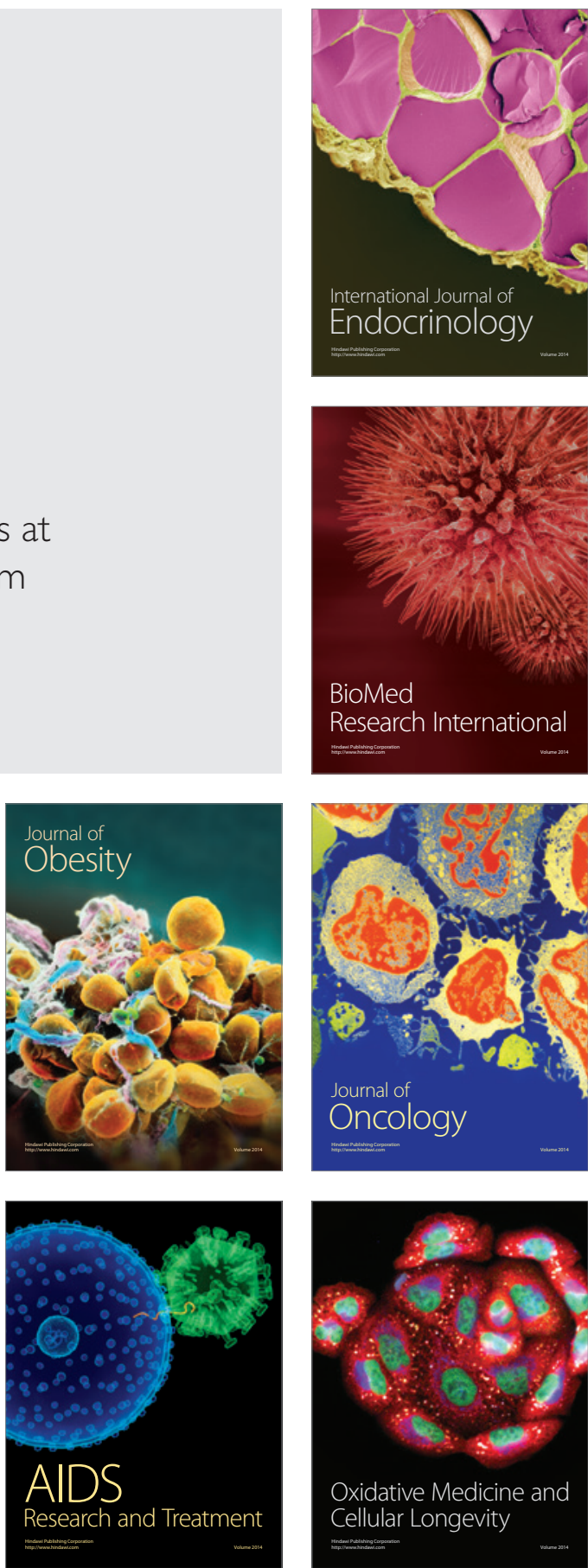